\title{
Chemical Modification of Yeast Farnesyl Protein Transferase Expressed in E. coli
}

\author{
Hyun-Kyung Kim ${ }^{\dagger}$ and Chul-Hak Yang* \\ ${ }^{\dagger}$ Hansung Science High School, Seoul 120-080, Korea. *E-mail: chulyang@plaza.snu.ac.kr \\ School of Chemistry, College of Natural Sciences, Seoul National University, Seoul 151-747, Korea \\ Received August 24, 2005
}

\begin{abstract}
Chemical modification of the $S$. cerevisiae farnesyl protein transferase (FPT) with CMC, phenylglyoxal and DEPC resulted in enzyme inactivation, depending upon the reagent concentration. The peptide substrate GSTPEP-I, a GST-fused undecapeptide mimicking the C-terminus of $\mathrm{p} 21^{\mathrm{Ki} \text {-ras }}$, protected the enzyme against inactivation by $\mathrm{CMC}$ which is specific to either aspartate or glutamate, while the other substrate farnesyl pyrophosphate (FPP) showed protection against phenylglyoxal which is the specific modifier of arginine residues, dependent on the substrate concentrations. Neither of the two substrates protected the enzyme against histidine inactivation by DEPC. It is suggested that there is at least one aspartate or glutamate residue at the peptide substrate binding site, and that at least one arginine residue is located at the binding site of FPP. There also seems to be at least one histidine residue which is critical for enzymic activity and is exposed toward the bulk solution, excluded from the substrate binding sites.
\end{abstract}

Key Words : Farnesyl protein transferase (FPT), Chemical modification, CMC, Phenylglyoxal, DEPC

\section{Introduction}

Post-translational modification by isoprenylation is now known as a mechanism which promotes membrane interactions and biological activity of various cellular proteins. ${ }^{1}$ Two converging lines of investigation have provided an important insight into the role of isoprenylated proteins in animal cells. One began with the studies on the structures of certain fungal mating factors. These mating factors were found to consist of a short peptide terminating in a cysteine residue to which a farnesyl group or, in one instance, an oxidized farnesyl group, is covalently linked. ${ }^{2,3}$ Later studies demonstrated that Ras proteins are farnesylated. ${ }^{4-6}$ Genes required for the post-translational maturation of both Ras and the peptide mating pheromone a-factor in $S$. cerevisiae were discovered, indicating that both polypeptides are processed via a common route. ${ }^{7,8}$ The other line of investigation began with studies concerning the cellular effects of compactin, an inhibitor of isoprenoid biosynthesis, and led to the discovery that mammalian cells contain a specific set of isoprenylated proteins including nuclear lamin B. ${ }^{9}$ Compactin (and also mevinolin or lovastatin) blocks isoprenylation by inhibiting $\mathrm{HMG}-\mathrm{CoA}$ reductase, the enzyme that catalyzes the synthesis of mevalonate (MVA), the precursor of cholesterol and all isoprenoids. ${ }^{10}$ The treatment of cells with high concentrations of compactin resulted in an arrest of cell growth before the $S$ phase that could not be reversed by exogenously added cholesterol or other sterols which are the major products of the isoprenoid pathway. ${ }^{11}$

The coding sequence of lamin B, Ras and a-factor indicated that the $\mathrm{C}$-termini of all these proteins contain the $\mathrm{CA}_{1} \mathrm{~A}_{2} \mathrm{X}$-motif, where $\mathrm{C}$ is the cysteine residue to which the isoprenoid is attached, $\mathrm{A}$ is an aliphatic amino acid and $\mathrm{X}$ is any amino acid. One such modification is conducted by fanesyl protein transferase (FPT) which catalyzes the transfer of the isoprenoid farnesyl from farnesyl pyrophosphate (FPP) to a cysteine residue in the $\mathrm{CA}_{1} \mathrm{~A}_{2} \mathrm{X}$ box of the protein substrates illustrated above. ${ }^{12-14}$ Farnesylation of Ras facilitates its membranes binding, which is essential for efficient cell transformation by oncogenic forms of Ras. ${ }^{4,6}$

According to some biochemical cross-linking studies ${ }^{15}$ and photoaffinity-labeling studies, the $\beta$ subunit possesses the binding domain for the protein substrates or the CAAX element. Also, there is an evidence from photo-crosslinking studies that an FPP binding site is located on the $\beta$ subunit $^{16}$ which is consistent with the different utilization of farnesyl $\left(\mathrm{C}_{15}\right)$ diphosphate and geranylgeranyl $\left(\mathrm{C}_{20}\right)$ diphosphate by FPT and GGPT-I, which appear to share a common $\alpha$ subunit and have similar but distinct $\beta$ subunits. ${ }^{17,18}$ Individually, the $\alpha$ and $\beta$ subunits are not catalytically active. ${ }^{15,19}$ Regarding the correlation of FPT structure and function, photoaffinity labeling studies indicates that the protein substrate binding locus of the FPT catalytic site lies in a cleft formed between the point of abutment of the $\alpha$ and $\beta$ subunits. The principal structural characteristics of the catalytic site domains of isoprenyl-protein transferase, however, remain unresolved.

In order to obtain information about what kinds of amino acid residues are involved in the active site(s) and/or the substrate binding site(s), chemical modification studies are routinely performed. Treatment of substrates, cofactors, effecters or inhibitors of enzymes is usually carried out to examine if those protect the binding site(s) or catalytic site(s) from inactivation against a given modifier. In this study, yeast FPT was expressed in E. coli as glutathione Stransferase (GST)-fused protein and purified by glutathioneagarose affinity column chromatography. Chemical modification studies were performed on the GST-fused FPT chiefly in view of amino acid residues having carboxylate side 
chains, arginine residues and histidine residues, with and without the protection of either GST-PEP-I or FPP, and the results are illustrated in this paper.

\section{Experimental Sections}

Materials. Glutathoine agarose (G-agarose), reduced glutathione, 1-cyclohexyl-3-(2-morpholinoethyl) carbodiimide metho- $p$-toluenesulfonate (CMC), phenylglyoxal, diethyl pyrocarbonate (DEPC) 1,3-diaza-2,4-cyclopentadiene (imidazole), dithiothreitol (DTT), $n$-octyl- $\beta$-glucopyranoside (OGP), Tris and $p$-methylsulfonyl fluoride (PMSF) were purchased from Sigma. $\left[1-{ }^{3} \mathrm{H}\right]$-farnesyl pyrophosphate $\left.\left({ }^{3} \mathrm{H}\right] \mathrm{FPP}, 22.5 \mathrm{Ci} / \mathrm{mmol}\right)$ was purchased from DuPont-New England Nuclear. A pFlag expression vector systems was purchased from Kodak IBI and a pGEX-4T-1 expression vector system was purchased from Promega. PCR primers were purchased from Bioneer Corp. Taq polymerase and Wizard PCR preps were purchased from Promega. Restriction enzymes were purchased from Promega, NEB, Kosko and MBI Fermentas.

$p F C R 2$, a recombinant $\mathrm{pFlag}$ with $R A M 2$ gene insert, and $p G R 1$, a recombinant pGEX-4T-1 with $R A M 1$ gene insert, were cloned. The undecapeptide fused to GST(GST-PEP I: [GST]-GCVKIKKCVIM) which has the peptide sequence homology with $\mathrm{p} 21^{\mathrm{K}-R a s} \mathrm{C}$-terminus was cloned, expressed in $E$. coli and purified to the concentration of $2.5 \mathrm{mg} / \mathrm{mL}$ in our laboratory, in order to be used as a substrate of FPT.

Chemical Modification with Various Reagents. Ten aliquots of $10 \mu \mathrm{L}$ of the purified yeast FPT in $50 \mathrm{mM}$ Tris-Cl (pH 7.5) were separately incubated with $4 \mathrm{mM} \mathrm{CMC}, 4 \mathrm{mM}$ DEPC, $8 \mathrm{mM}$ phenylglyoxal, $4 \mathrm{mM}$ N-bromosuccimide (NBS), $4 \mathrm{mM}$ maleic anhydride, $4 \mathrm{mM}$ succinic anhydride, 4 $\mathrm{mM}$ PMSF, $4 \mathrm{mM}$ iodoacetate, $2.5 \mathrm{mM}$ pyridoxal-5phosphate (PLP) and $4 \mathrm{mM} \mathrm{H}_{2} \mathrm{O}_{2}$, respectively at $25{ }^{\circ} \mathrm{C}$ in the dark for $15 \mathrm{~min}$. The stock solutions of the modifying reagents used above were prepared as $50 \mathrm{mM}$ Tris-Cl buffered solution, except CMC, DEPC, phenylglyoxal and NBS which were dissolved in $100 \%$ ethanol. The concentrations of the stock solutions of these reagents dissolved in ethanol were adjusted to ensure that the amount of added ethanol did not disturb the enzymic activity. Intact enzyme and enzyme treated with $1 \%$ final concentration of ethanol were both used as positive controls. The reaction mixture was diluted with PBS buffer, up to $50 \mu \mathrm{L}$ total volume. Each $25 \mu \mathrm{L}$ aliquot out of the respective reaction mixture was subjected to assay for FPT activity.

Specific Modification of Aspartates and Glutamates with CMC. $100 \mathrm{mM}$ stock solution of water-soluble carbodiimide CMC which is specific for aspartates and glutamates having carboxyl group side chains was prepared by dissolving it in $50 \mathrm{mM}$ Tris- $\mathrm{Cl}(\mathrm{pH} 7.5)$. The enzyme was first tested to see if the quenching method of four-fold dilution with $20 \mathrm{mM}$ potassium acetate treatment works without disturbing the reagent-untreated enzyme and if either of the substrates protect the enzyme against modification by CMC for a 10 min period. Then five sets of $60 \mu \mathrm{L}$ volume of the enzyme was incubated with $1 \mathrm{mM}, 2 \mathrm{mM}, 3$ $\mathrm{mM}, 8 \mathrm{mM}$ and $10 \mathrm{mM}$ concentration of CMC, respectively at $25^{\circ} \mathrm{C}$ for $50 \mathrm{~min}$. At the intervals of 10 minutes, $10 \mu \mathrm{L}$ samples of the reaction mixtures were withdrawn and added to $30 \mu \mathrm{L}$ of $20 \mathrm{mM}$ potassium acetate buffer at $\mathrm{pH} 7.0$ and cooled in ice to minimize further reaction. The remaining activity of the diluted enzyme derivatives was determined by the FPT assay method described above. In a parallel experiment, reactions with the enzyme and $10 \mathrm{mM} \mathrm{CMC}$ were performed for three sets of $60 \mu \mathrm{L}$ enzyme preincubated with varying concentrations of GST-PEP-I substrate at $25{ }^{\circ} \mathrm{C}$ for $10 \mathrm{~min}$. As an analogy, enzyme sets treated with varying concentrations of FPP were likewise tested.

Specific Modification of Arginine Residues with Phenylglyoxal. $100 \mathrm{mM}$ and $10 \mathrm{mM}$ stock solutions of phenylglyoxal which is specific for arginine residues were prepared by dissolving it in $100 \%$ ethanol. A quenching solution of $200 \mathrm{mM}$ free $\mathbf{L}$-arginine- $\mathrm{HCl}$ was prepared as a Tris-Cl buffer solution at $\mathrm{pH}$ 7.5. The enzyme was first tested to see if the quenching method of four-fold dilution with $200 \mathrm{mM}$ free L-arginine-HCl worked without disturbing the reagent-untreated enzyme and if either of the substrates protects the enzyme against modification by phenylglyoxal for a $10-\mathrm{min}$ period. Then five sets of $60 \mu \mathrm{L}$ volume of the enzyme were incubated with $0.1 \mathrm{mM}, 1 \mathrm{mM}$, $2 \mathrm{mM}, 3 \mathrm{mM}$ and $4 \mathrm{mM}$ concentration of phenylglyoxal, respectively at $25{ }^{\circ} \mathrm{C}$ in the dark for $50 \mathrm{~min}$. At the interval of 10 minutes, $10 \mu \mathrm{L}$ samples of the reaction mixtures were withdrawn and added to $30 \mu \mathrm{L}$ of $200 \mathrm{mM}$ free $\mathbf{L}$-arginine$\mathrm{HCl}$ and cooled in ice to minimize further reaction. The remaining activity of the diluted enzyme derivatives was determined by the FPT assay method described above. In a parallel experiment, reactions with the enzyme and $4 \mathrm{mM}$ phenylglyoxal were performed for three sets of $60 \mu \mathrm{L}$ enzyme pre-incubated with varying concentrations of GSTPEP-I substrate at $25{ }^{\circ} \mathrm{C}$ for 10 min. Enzyme sets treated with varying concentrations of FPP were tested likewise.

Specific Modification of Histidine Residues with DEPC. Approximately $1 \mathrm{mM}, 10 \mathrm{mM}$ and $100 \mathrm{mM}$ stock solutions of DEPC, which is specific for histidine residues were prepared by dissolving it in $100 \%$ ethanol. The quenching solution of $50 \mathrm{mM}$ imidazole was prepared as Tris-Cl buffer solution at $\mathrm{pH}$ 7.5. The enzyme was first tested to see if the quenching method of four-fold dilution with $50 \mathrm{mM}$ imidazole works without disturbing the reagent-untreated enzyme and if either of the substrates protect the enzyme against modification by DEPC for 10 min. Then five sets of $60 \mu \mathrm{L}$ volume of the enzyme were incubated with $0.01 \mathrm{mM}, 0.1 \mathrm{mM}, 1 \mathrm{mM}, 5 \mathrm{mM}$, and $10 \mathrm{mM}$ concentration of phenylglyoxal, respectively at $25^{\circ} \mathrm{C}$ in the dark for $50 \mathrm{~min}$. At intervals of 10 minutes, $10 \mu \mathrm{L}$ samples of the reaction mixtures were withdrawn and added to $30 \mu \mathrm{L}$ of $50 \mathrm{mM}$ imidazole and cooled in ice to minimize further reaction. The remaining activity of the diluted enzyme derivatives was determined by the FPT assay method described above. In a parallel experiment, reactions with the 
enzyme and $5 \mathrm{mM}$ DEPC were performed for three sets of $60 \mu \mathrm{L}$ enzyme pre-incubated with varying concentrations of GST-PEP-I substrate at $25{ }^{\circ} \mathrm{C}$ for $10 \mathrm{~min}$. Enzyme sets treated with varying concentrations of FPP were tested likewise.

\section{Results and Discussion}

Chemical Modification with Various Reagents. Various reagents were used to search for the amino acid residues in the protein which might be critical for enzymatic activity (Table 1). Enzyme portions treated with some reagents showed a conspicuous decrease in activity (Fig. 1). It is shown at first that less than $1 \%$ concentration of ethanol does not disturb the enzymic activity. It is highly probable that aspartate (or glutamate), histidine, and arginine residues, specifically modified by CMC, DEPC and phenylglyoxal, respectively, are critical for the enzymic activity. Tryptophanyl modification by NBS and lysinyl modification by maleic anhydride or succinyl anhydride might have comparably affected the activity. Serine or threonine modification by PMSF seems not to inhibit the enzymatic activity, ruling out the possibility that the serinyl or threoninyl hydroxyl group might participate in the catalysis. Iodoacetate, with relatively low specificity, must have preferentially modified cysteines or methionines, which are considered to influence the activity only slightly, because the slight inactivation excludes the possibility of the modification of histidine which is proven critical, and lysine which does not clearly affect the activity totally as seen from the partial inactivation by PLP, although the reagent usually modifies cysteine, histidine, lysine and methionine, amino acids having potent nucleophillic side chain functional groups. Hydrogen peroxide must have mostly affected the easily oxidizable amino acids (His, Trp, Met and Cys) and/or have induced conformational change by forming undesirable disulfide linkages. In conclusion, aspartate, glutamate, histidine and arginine are the most probable, tryphtophan and lysine are less probable, and serine and threonine are the least probable amino acids that participate in the substrate

Table 1. Various Modifying Reagents for the amino residues in the FPT

\begin{tabular}{cc}
\hline Reagent & Modified Functional Groups \\
\hline CMC & Asp, Glu, (Cys, Tyr ${ }^{\circledR}$ \\
DEPC & His \\
Phenylglyoxal & Arg, (Lys, His) ${ }^{\circledR}$ \\
NBS & Trp \\
Maleic anhydride & Lys \\
Succinic anhydride & Lys, Tyr \\
PMSF & Ser, Thr \\
Iodoacetate & Cys, His, Lys, Met \\
PLP & Lys \\
Hydrogen peroxide & His, Met, Trp, Cys, cystine \\
DTT & Cystine \\
\hline
\end{tabular}

( (a), (b) : reported minor side reactions)

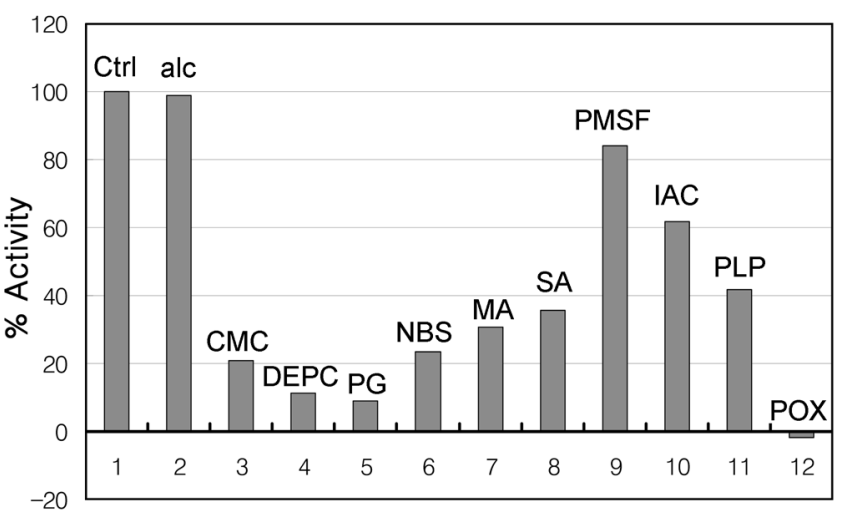

Figure 1. FPT activity for Chemical Modification with Various Reagents. (1) FPT (FPT activity was determined by measurement of the amounts of $\left[{ }^{3} \mathrm{H}\right]$ farnesyl transferred from $\left[{ }^{3} \mathrm{H}\right] \mathrm{FPP}$ to GSTCVIM protein, 32,000 Ci/mmol, (2) FPT $+1 \%$ Ethanol (FPT activity was $31,680 \mathrm{Ci} / \mathrm{mmol}$, was used as control), (3) FPT +4.0 mM CMC (FPT activity was $6652.8 \mathrm{Ci} / \mathrm{mmol}$, was inhibited by $21 \%$ at $4.0 \mathrm{mM} \mathrm{CMC}$ ), (4) FPT $+4.0 \mathrm{mM}$ DEPC (FPT activity was $3484.8 \mathrm{Ci} / \mathrm{mmol}$, was inhibited by $11 \%$ at $4.0 \mathrm{mM} \mathrm{DEPC}$ ), (5) FPT + 4.0 mM Phenylglyoxal (FPT activity was $2534.4 \mathrm{Ci} / \mathrm{mmol}$, was inhibited by $8 \%$ at $4.0 \mathrm{mM} \mathrm{PG}$ ), (6) FPT $+4.0 \mathrm{mM}$ NBS (FPT activity was $7603.2 \mathrm{Ci} / \mathrm{mmol}$, was inhibited by $24 \%$ at $4.0 \mathrm{mM}$ NBS), (7) FPT + 4.0 mM Maleic Anhydride (FPT activity was $9820.8 \mathrm{Ci} / \mathrm{mmol}$, was inhibited by $31 \%$ at $4.0 \mathrm{mM} \mathrm{MA}$ ), (8) FPT + $4.0 \mathrm{mM}$ Succinic Anhydride (FPT activity was $11404.8 \mathrm{Ci} / \mathrm{mmol}$, was inhibited by $36 \%$ at $4.0 \mathrm{mM} \mathrm{SA}$ ), (9) FPT $+4.0 \mathrm{mM}$ PMSF (FPT activity was $26611.2 \mathrm{Ci} / \mathrm{mmol}$, was inhibited by $84 \%$ at 4.0 mM PMSF), (10) FPT $+4.0 \mathrm{mM}$ Iodoacetate (FPT activity was $19324.8 \mathrm{Ci} / \mathrm{mmol}$, was inhibited by $61 \%$ at $4.0 \mathrm{mM} \mathrm{IAC}$ ), (11) FPT $+2.5 \mathrm{mM}$ PLP (FPT activity was $13305.6 \mathrm{Ci} / \mathrm{mmol}$, was inhibited by $42 \%$ at $4.0 \mathrm{mM} \mathrm{PLP}$ ), (12) FPT $+4.0 \mathrm{mM} \mathrm{H}_{2} \mathrm{O}_{2}$ (FPT activity was $31046.4 \mathrm{Ci} / \mathrm{mmol}$, was inhibited by $-2 \%$ at $4.0 \mathrm{mM} \mathrm{H}_{2} \mathrm{O}_{2}$ )

binding and/or catalysis of yeast FPT.

Specific Modification of Aspartates and Glutamates with CMC. Carbodiimides exhibit high selectivity for carboxylate residues in proteins. An initial O-acylisourea intermediate is formed by addition to the carbodiimide, which in aqueous solution may either react with an amine or may rearrange to form a more stable $\mathrm{N}$-acylurea, in either case transforming the carboxylate. Most of the current work utilizes water-soluble carbodiimides, among which CMC was chosen for modification of yeast FPT. The possible minor modification of tyrosines could be reversed by hydroxyl amine treatment. In the preliminary test, $20 \mathrm{mM}$ potassium acetate quenching method was proven to work and did not disturb enzymatic activity. $1.9 \mu \mathrm{M}$ GST-PEP-I showed almost perfect protection and $0.22 \mu \mathrm{M}$ FPP showed only partial protection (Fig. 2). Increased concentration of $\mathrm{CMC}$ accelerated inactivation as a function of incubation time (Fig. 3). Inactivation rates produced by $\mathrm{CMC}$ in the presence of either of the two substrates were studied to determine if substrates would protect the enzyme from inactivation by CMC. Protection studies were performed by preincubating the enzyme with $1.9 \mu \mathrm{M}$ and $3.8 \mu \mathrm{M}$ concentrations of GST-PEP-I protector followed by incubation with the modifier. Increased concentration of GST-PEP-I protected the enzyme with increased efficiency against modifi- 


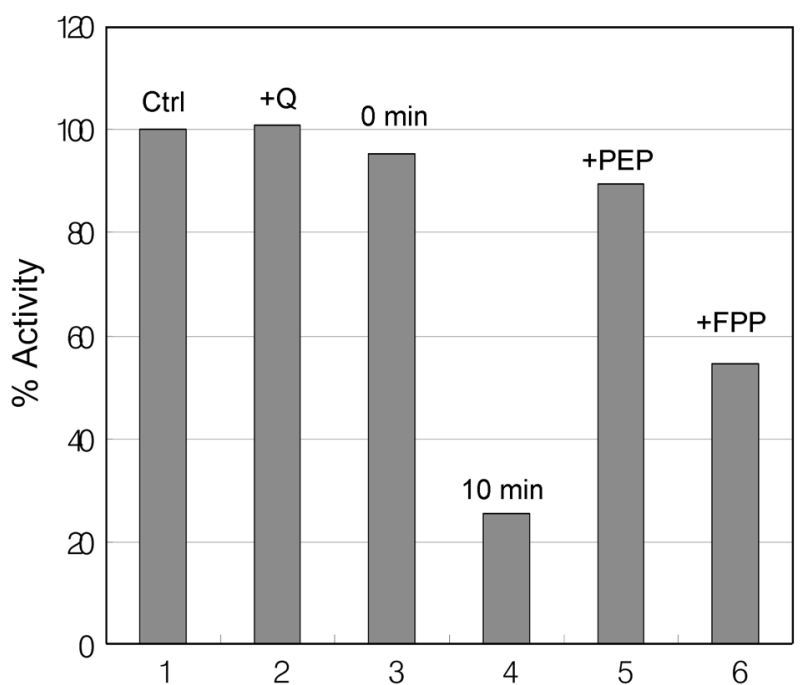

Figure 2. Overview Modification of FPT by CMC (1-cyclohexyl3-(2-morpholinoethyl) carbodiimide metho- $p$-toluenesulfonate; aspartate, glutamate modification reagent), (1) Control, (2) Effect of $20 \mathrm{mM}$ AcOK quenching, (3) Quenched aliquot at $0 \mathrm{~min}$, (4) Quenched aliquot at $10 \mathrm{~min}$, (5) Protection by GST-PEP-I, (6) Protection by FPP

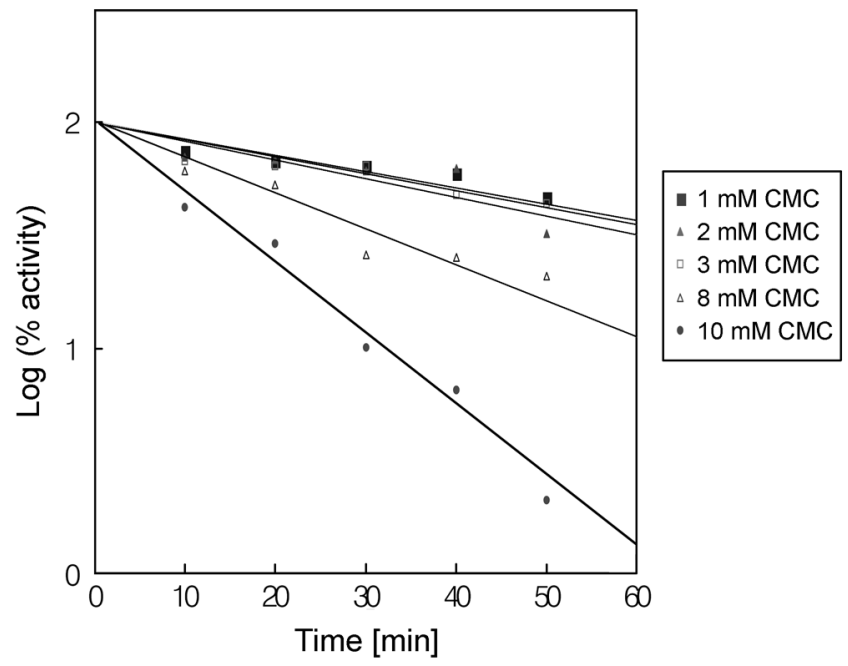

Figure 3. Kinetics of FPT inactivation by CMC (1-cyclohexyl-3(2-morpholinoethyl) carbodiimide metho- $p$-toluenesulfonate).

cation by CMC (Fig. 4).

Specific Modification of Arginine Residues with Phenylglyoxal. While it is somewhat more difficult to obtain the site-specific modification of arginine, the groupspecific modification of arginine is relatively easy to achieve. Arginine residues are usually involved in binding sites rather than catalytic sites. Enzyme arginine residues are known to play an important role in binding anionic substrate(s), cofactor(s) or effector(s). The role of arginine residues in enzymatic activity can be studied by using specific arginine modifiers such as phenylglyoxal and 2,3butanedione. The guanidine moiety capping the side chain of the amino acid arginine characteristically adds to these 1,2dicarbonyl compounds. The use of phenylglyoxal was developed by Takahashi ${ }^{20}$ and has since been applied to the

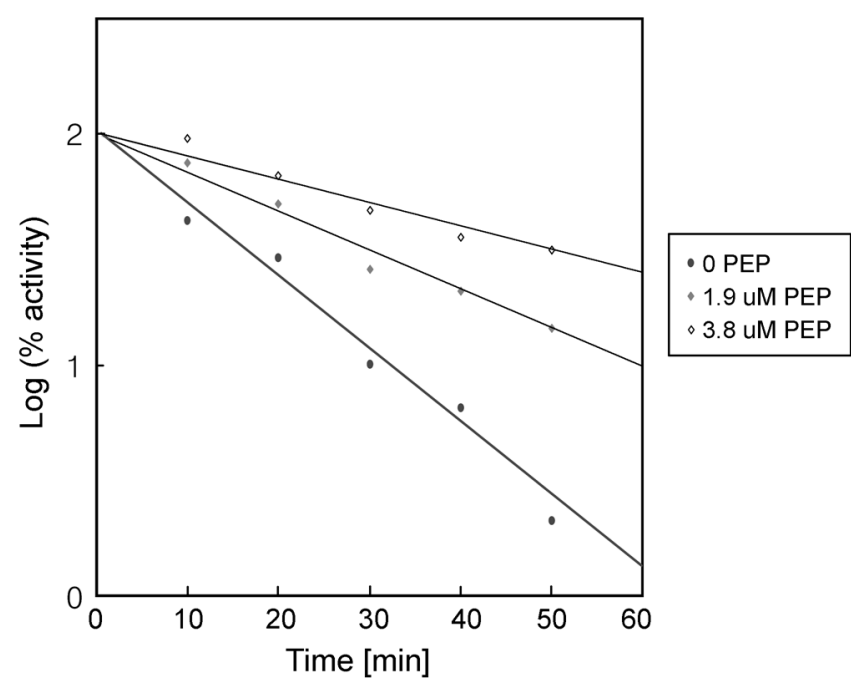

Figure 4. Kinetics of FPT protection by GST-PEP-I against CMC (1-cyclohexyl-3-(2-morpholinoethyl) carbodiimide metho- $p$ toluenesulfonate).

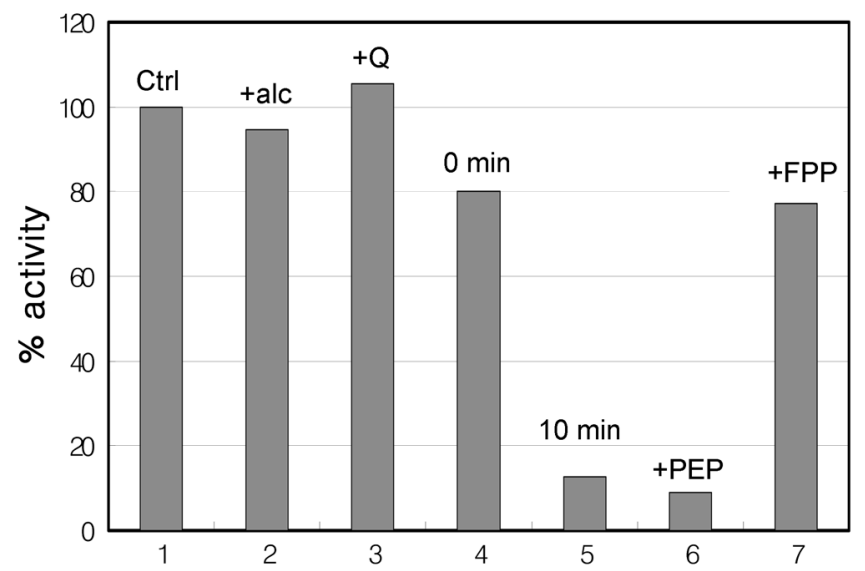

Figure 5. Overview Modification of FPT by phenylglyoxal (arginine modification reagent) (1) Control, (2) Effect of 1\% EtOH addition, (3) Effect of $200 \mathrm{mM}$ L-arginine quenching, (4) Quenched aliquot at $0 \mathrm{~min}$, (5) Quenched aliquot at $10 \mathrm{~min}$, (6) Protection by GST-PEP-I, (7) Protection by FPP

study of the role of arginine residues in proteins. Phenylglyoxal, like glyoxal, will react with $\alpha$-amino groups at a significant rate. As noted by Takahashi, the stoichiometry of the reaction involves the reaction of $2 \mathrm{~mol}$ of phenylglyoxal with $1 \mathrm{~mol}$ of arginine. Although arginine modification by 1,2-dicarbonyl compounds are usually performed in carbonate buffers, phosphate buffers or borate buffers, a Tris buffer solution of the enzyme was used in this study. Enzymes may be protected from inactivation by dicarbonyl reagents by the presence of substrates that bind at arginine residues. Ribulose bisphosphate carboxylase is protected by ribulose bisphosphate, ${ }^{21}$ NADPH-dependent aldehyde reductase is protected by NADPH, ${ }^{22}$ and pyruvate kinase is protected by ATP and phosphoenolpyruvate.

In the preliminary test, $200 \mathrm{mM} \mathrm{L}$-arginine- $\mathrm{HCl}$ quenching proved almost successful without disturbing the enzymatic action. A control treated with $1 \%$ ethanol also 


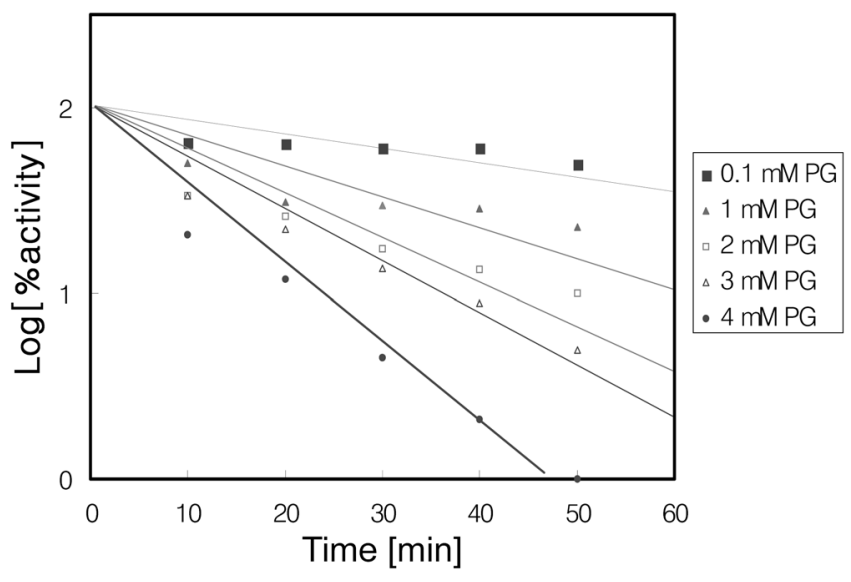

Figure 6. Kinetics of FPT inactivation by phenylglyoxal.

showed no disruption of enzymatic action. 1.9 $\mu \mathrm{M}$ GSTPEP-I offered little protection and $0.22 \mu \mathrm{M}$ FPP offered almost perfect protection against modification by phenylglyoxal (Fig. 5) To calculate the kinetics of inactivation by phenylglyoxal, the logarithm of enzyme activity remaining was plotted as a function of incubation time at various phenylglyoxal concentrations (Fig. 6). Inactivation rates produced by phenylglyoxal in the presence of either of the two substrates were studied to determine if substrates would protect the enzyme from inactivation by phenylglyoxal. Protection studies were performed by preincubating the enzyme with $1.9 \mu \mathrm{M}$ and $3.8 \mu \mathrm{M}$ concentrations of GSTPEP-I protector followed by incubation with the modifier. Increased concentration of FPP protected the enzyme with increased extent against modification by phenylglyoxal (Fig. 7).

Specific Modification of Histidine Residues with DEPC. Since many enzymes contain a histidine residue, which is critical for the catalytic process, the site-specific modification of this residue has been the subject of many studies. Only DEPC (ethoxy formic anhydride) is currently used for the modification of histidine in proteins. Because histidine, together with methionine and tryphtophan, is quite sensitive to photooxydation, while tyrosine, serine and threonine are somewhat less sensitive, the reaction mixture had been strictly kept in the dark.

In the preliminary test, $50 \mathrm{mM}$ imidazole quenching

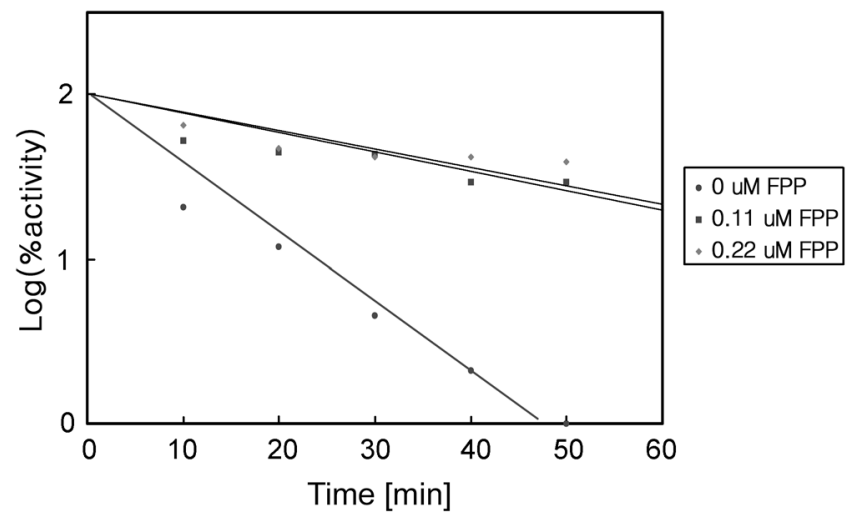

Figure 7. Kinetics of FPT protection by FPP against phenylglyoxal.

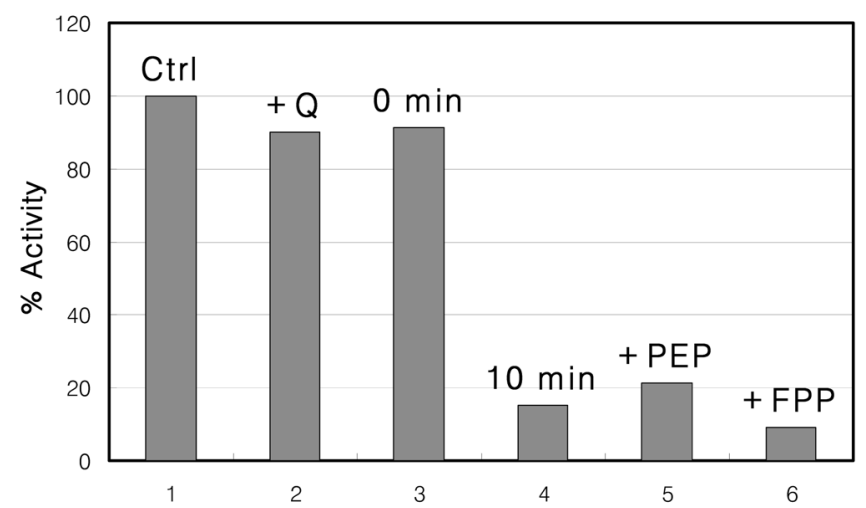

Figure 8. Overview Modification of FPT by DEPC(cysteine, histidine, tyrosine modification reagent), (1) Control, (2) Effect of $50 \mathrm{mM}$ imidazole quenching, (3) Quenched aliquot at $0 \mathrm{~min}$, (4) Quenched aliquot at $10 \mathrm{~min}$, (5) Protection by GST-PEP-I, (6) Protection by FPP.

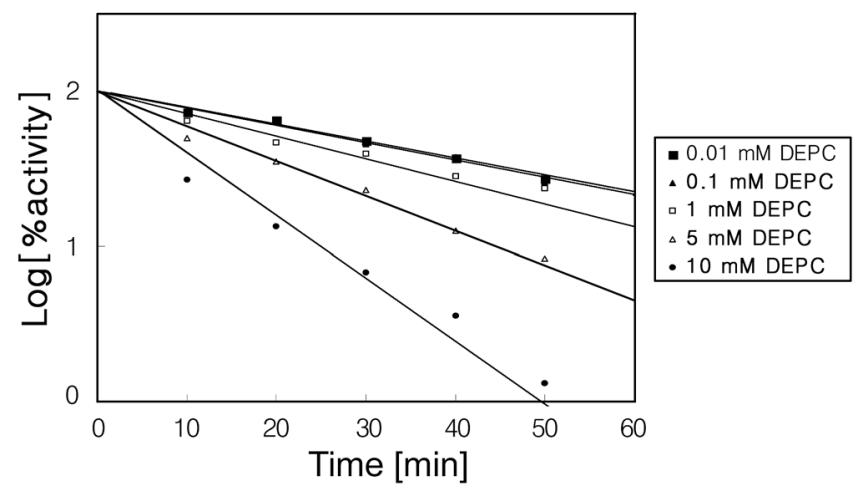

Figure 9. Kinetics of FPT inactivation by DEPC.

proved almost successful without disturbing the enzymatic action. Both $1.9 \mu \mathrm{M}$ GST-PEP-I and $0.22 \mu \mathrm{M}$ FPP showed little protection against modification by DEPC (Fig. 8) Increased concentration of DEPC accelerated inactivation as a function of incubation time (Fig. 9). Inactivation rates produced by DEPC in the presence of either of the two substrates were studied to determine if substrates would protect the enzyme from inactivation by DEPC. Protection studies were performed by preincubating the enzyme with $1.9 \mu \mathrm{M}$ and $3.8 \mu \mathrm{M}$ concentrations of GST-PEP-I protector followed by incubation with the modifier. Both substrates showed little protection, implying that the substrate binding sites and catalytic site do not about tightly. Histidine residues within an $\alpha$ subunit ( $\alpha \mathrm{H} 145)$ and a $\beta$ subunit ( $\beta \mathrm{H} 258)$ had been proven critical for the enzymatic activity of yeast FPT from previous reports. The inactivation by DEPC must have modified both or either of the two histidine residues.

\section{Conclusions}

Although little is exactly proved about the structure of the active site of FPT, some hypothetical suggestions are set forth. The results of the studies of the substrates and metal cofactors had previously suggested that FPP binds to the $\beta$ subunit and the peptide substrate binds into the interface 
between the two subunits. $\mathrm{Zn}^{2+}$ seems essential for peptide binding and attached to the $\beta$ subunit which discriminates FPP and GGPP. Prenyl pyrophosphate does not require any cation for binding, while transfer of the bound preny group to the bound peptide acceptor requires $\mathrm{Mg}^{2+}$. And the proposed kinetic mechanism is simple random-ordered, two substrate reaction, where FPP and peptide can bind to the enzyme in any order.

A hypothetical model of the active site of FPT was suggested on the grounds of inhibitor studies. ${ }^{23}$ The reaction formally proceeds by a nucleophilic attack by the thiol group of cysteine on the allylic carbon of FPP bearing the pyrophosphate leaving group. An enzymatic base may facilitate the reaction by abstracting the thiol proton and enhancing the nucleophilicity of the thiol group. $\mathrm{Mg}^{2+}$ may serve to complex with the PP group in order to neutralize the charge and set the stage for a transfer reaction. It may be coordinated with the thiol and/or with the free $\mathrm{COOH}$ group of Ras, or it may simply serve to stabilize the heterodimeric form of the enzyme.

Comparison of known genes of human, bovine, murine and $S$. cerevisiae FPT in terms of sequence homology led to some results concerning site-directed mutageneses of either of the two subunits. As previously shown, the mutant $\alpha \mathrm{N} 143 \mathrm{~K}$ primarily affected CVIM peptide utilization, and $\beta \mathrm{D} 209 \mathrm{~N}$ of ram 1-1 allele increased the $\mathrm{K}_{\mathrm{m}}$ values for CVIM. The results of similar studies previously conducted in our lab showed $\alpha \mathrm{H} 145 \mathrm{D}$ had increased $\mathrm{K}_{\mathrm{m}}$ for peptide and is proposed to be involved in the peptide binding. $\beta \mathrm{H} 258 \mathrm{~A}$ also showed lowered activity.

In summary, it is speculated that $\alpha \mathrm{H} 145, \alpha \mathrm{N} 143$ and $\beta \mathrm{D} 209$ are positioned at the CAAX box (peptide binding domain), one or two of which subunits may be coordinated to $\mathrm{Zn}^{2+}$ or act as an enzymatic base extracting a thiolic proton while stabilizing the transition state of the nucleophilic attack of the sulfur atom of cysteine. $\beta \mathrm{H} 258$ may also serve one of these roles. $\beta$ D209 is the residue most probably affected by CMC modification. Arginine residue(s) may tightly bind anionic pyrophosphate leaving a group of
FPP which is shown to protect against modification by phenylglyoxal.

\section{References}

1. Casey, P. J. J. Lipid Res. 1992, 33, 1731-1740.

2. Kamiya, Y.; Sakurai, A.; Tamura, S.; Takahashi, A. Biochem. Biophys. Res. Common. 1978, 83, 1077-1083.

3. Ishibashi, Y.; Sakagami, Y.; Isogai, A.; Suzuki, A. Biochemistry 1984, 23, 1399-1404.

4. Hancock, J. F.; Magee, A. I.; Childs, J. E.; Marshall, C. J. Cells 1989, 57, 1167-1177.

5. Schafer, W. R.; Kim, R.; Sterne, R.; Thorner, J.; Kim, S. H.; Rine, J. Science 1989, 245, 379-385.

6. Casey, P. J.; Solski, P. A.; Der, C. J.; Buss, J. E. Proc. Natl. Acad. Sci. USA 1989, 86, 8323-8327.

7. Shafer, W. R.; Rine, J. Annu. Rev. Genet. 1992, 25, 209-238.

8. Powers, S.; Michaelis, S.; Broek, D.; Santa-Ana, A. S.; Field, J. et al. Cells 1986, 47, 413-422.

9. Glomset, J. A.; Gelb, M. H.; Farnsworth, C. C. Trends Biochem. Sci. 1990, 15, 139-142.

10. Goldstein, J. L.; Brown, M. S. Nature 1990, 343, 425-430.

11. Brown, M. S.; Goldstein, J. L. J. Lipid. Res. 1980, 21, 505-517.

12. Reiss, Y.; Goldstein, J. L.; Seabra, M. C.; Casey, P. J.; Brown, M. S. Cell 1990, 62, 81-88.

13. Schaber, M. D. et al. JBC 1990, 265, 14701-14704.

14. Manne, V. et al. Proc. Natl. Acad. Sci. USA 1990, 87, 75417545.

15. Reiss, Y.; Brown, M. S.; Goldstein, J. L. J. Biol. Chem. 1992, 267, 6403-6408.

16. Omer, C. A.; Kral, A. M.; Dzehl, R. E.; Prendergast, G. C.; Powers, S.; Allen, C. M.; Gibbs, J. B.; Kohl, N. E. Biochemistry 1993, 32, 5167-5176.

17. Moores, S. L. et al. JBC 1991, 266, 14603-14610.

18. Seabra, M. C.; Reiss, Y.; Casey, P. J.; Brown, M. S.; Goldstein, J. L. Cell 1991, 65, 429-434.

19. Chen, W. J.; Andress, D. A.; Goldstein, J. L.; Russell, D. W.; Brown, M. S. Cell 1991, 66, 327-334.

20. Takahashi, K. JBC 1988, 243, 6171.

21. Schloss, J. V.; Norton, I. L.; Stringer, C. D.; Hartman, F. C. Biochemistry 1978, 17, 5626-5631.

22. Davidson, W. S.; Flynn, T. G. JBC 1979, 254, 3724-3729.

23. Berghauser, J. Hoppe-Seyler's Z. Physiol. Chem. 1977, 358, 15651572.

24. Patel, D. V. JMC 1995, 38, 435-442. 